Scientific Bulletin, № 2, 2021, pages 124-132

Aferin Ali Abbasova, ismayilovasevda38@gmail.com

Western Caspian University

DOI: doi.org/10.54414/qkba2324

e-ISSN: $2789-4614$

\title{
COMPARATIVE ANALYSIS OF THE CONCEPTS OF TRUSTAND CONFIDENCE IN PSYCHOLOGY
}

\section{ABSTRACT}

In the article, it is shown that in psychology, they have been tried to explain the differences and similarities between the concepts of trust and confidence. The author also brings to focus on analyzing the psychological analysis of the concepts of trust and confidence in the different systems of sciences. In the article, it is noted by researchers while it is explaining the essence of the problem of trust in psychology, trust is not only a concept but also it is having a social and interpersonal function in human relations. By the author also is shown that belief is one of the most important components in the structure of the spiritual world of person existing.

In the article analysis of the works devoted to the studying of the concepts of trust and confidence shows that these two concepts require seriousscientific research as a psychological problem.

Key words: The concept of trust, the concept of belief, ethical category, philosophical ethics, moral category, psychological analysis, comparative analysis, moral value, moral consciousness, moral attitude, analysis, object, subject

\section{PSIXOLOGIYYADA ETIMAD VO İNAM ANLAYIŞLARININMÜQAYISSəLİ TOHLİLi}

\section{XÜLASə}

Məqalədə göstərilir ki, psixologiyada etimad və inam anlayışlarını fərqli və oxşar tərəflərini izah etməyə çalışıblar. Həmçinin, müəllif etimad və inam anlayışlarının ayrı-ayrı elmlər sistemində psoxoloji baxımdan təhlilini diqqət mərkəzinə gətirir. Məqalədə psixologiyada etimad probleminin mahiyyətini açarkən, tədqiqatçılar etimadı yalnız anlayışlar kimi yox, həm də onu insan münasibətlərində sosial və şəxsiyyətlərarası funksiya daşıdığ1 qeyd olunur. Eləcə də müəllif tərəfindən inam insanın mənəvi aləminin strukturunda yer tutan ən önəmli komponentlərdən biri olduğu göstərilir.

Məqalədə etimad və inam anlayışlarının öyrənilməsinə həsr olunmuş işlərin təhlili göstərir ki, bu iki anlayış psixoloji problem olaraq ciddi elmi araşdırma tələb edir.

Açar sözlər: Etimad anlayışı, inam anlayışı, etik kateqoriya, fəlsəfi etika, əxlaq kateqoriya, psixoloji təhlil, müqayisəli təhlil, əxlaqi dəyər, əxlaqi şüur, əxlaqi münasibət, təhlil, obyekt, subyekt

\section{СРАВНИТЕЛЬНЫЙ АНАЛИЗ КОНЦЕПЦИЙ ДОВЕРИЯ ИУВЕРЕННОСТИ В ПСИХОЛОГИИ}

\section{РЕЗЮМЕ}

В статье показано, что автор пытается объяснить различия и сходства в психологии между понятиями доверия и уверенности. Он также акцентирует внимание на психологическом анализе концепций доверия и уверенности в различных системах наук. Объясняя природу проблемы доверия в психологии, исследователь отмечает, что доверие является не только концепцией, но также выполняет социальную и межличностную функцию в человеческих отношениях. Автор также утверждает, что вера является одним из важнейших компонентов в структуре духовного мира человека.

Анализ работ, посвященных изучению понятий доверия и уверенности в статье, показывает, что эти два понятия требуют серьезного научного исследования.

Ключевая слова: Понятие доверия, понятие веры, этическая категория, философская этика, моральная категория, психологический анализ, сравнительный анализ, моральная ценность, моральное сознание, нравственное отношение, анализ, объект, субъект 
Antropoloji elmlər sistemində, etimad və inam anlayışlarını adətən, əxlaqi-etik kateqoriyalara aid edirlər. Etimad kateqoriyasının etik-fəlsəfi təhlili tək konkret insanların arasında münasibətlərin öyrənilməsinə deyil, həm də şəxs və cəmiyyət, şəxs və dövlət, şəxs və kollektiv, millətlər və dövlətlərarası münasibətlərin tədqiqinə yönəlmişdir. Bununla əlaqədar etimad və inam anlayışını bütöv psixoloji hadisə kimi dərk etmək zərurəti yaranır (1, səh.243).

Psixoloji ədəbiyyatlarda əksər tədqiqatçılar (B.Rutkovski, Y.Yançev V.Qubenko) etimad və inam anlayışlarını fərqli və oxşar tərəflərini izah etməyə çalışıblar.

Fəlsəfi etikada etimad insanlar arasında mənəvi münasibətləri əks etdirən etik kateqoriya kimi götürülür. Tədqiqatçılar eyni zamanda qeyd edir ki, etimad kateqoriyası əslində Aristotel, Spinoza, Kant və Hegelin fəlsəfi-etik sistemlərində təqdim olunmayıb. Bu filosoflar öz işlərində həmin hadisəyə toxunublar, lakin onu xüsusi qeyd etməyiblər.

Etimada həsr olunmuş çox azsaylı etik tədqiqatlarda, ilk növbədə onun sosial mənşəyi qeyd olunur. Hesab olunur ki, etimad-əxlaqi şüurun uzunmüddətli inkişafı nəticəsində şəxsiyyətlərarası konkret münasibətlər praktikasından yaranır, sonradan isə fəlsəfəyə müstəqil anlayış kimi daxil olaraq nəzəri təhlil obyektinə çevrilir.

Psixoloji ədəbiyyatlarda "etimad göstərmək" (latın dilində-credo) "ürəyimi verirəm" və ya "ürəyimə qoyuram" mənasını verir (5, s.365).

Aparılmış tədqiqatlar göstərir ki, etimad anlayışında etik nöqteyi-nəzərdən insanların həm şəxsi, həm ictimai həyatında könüllü qarşılıqlı öhdəliklərlə bağlı olan əxlaq normaları ənənəvi olaraq əks olunur. Etimadlı münasibətlər dedikdə, qarşılıqlı könüllü öhdəçiliklə, mənəvi borca əsaslanan münasibətlər nəzərdə tutulur. Bu öhdəliklər nəticə etibarı ilə bəşəriyyətin uzunmüddətli inkişafı ərzində əldə olunub və cəmiyyət tərəfindən şəxsiyyətə təqdim olunur. Lakin, bu kateqoriyanı işləyən bütün müəlliflər qeyd edir ki, etimad mənəvi şüurun keyfiyyətcə xüsusi bir halıdır ki, insanın davranışının motiv və stimulları olan mənəvi hiss və fikirləri özündə birləşdirir. Bu konteksdə etimad mənəvi münasibətlərin tənzimləyicisi qismində çıxış edir və filosoflar məhz bunda onun əsas funksiyasını görürlər. Beləliklə, belə bir qənatə gələ bilərik ki, etimad insanın digər insanlarla xarici əlaqələrin subyektiv sferasına daxil olur və bu münasibətlərin tənzimlənməsi funksiyasını yerinə yetirir.

Ümumiyyətlə, fəlsəfi etikada bir sıra tədqiqatlar var ki, etimad problemini əxlaqın etik kateqoriyası kimi öyrənir və bunun başqa elmlərin kateqorial aparatından çıxarır. Burda problemin əsas məzmunu etimad hadisəsinin mahiyyət xarakteristikasını ayırd etməkdir. Məsələn, B.Rutkovskinin nöqteyinəzərindən etimad elə bir əxlaqi anlayışdır ki, bu hər hansı bir şəxsdə digər şəxsin namuslu, düzgün, sədaqətli, məsuliyyəti olmasına əminliyindən sonra yaranır (9, s.12).

B. Rutkovski etimadın formalaşmasının obyektiv və subyektiv şərtlərini 
təyin etməуə, etimadın digər etik kateqoriyalar arasında spesifikasını və yerini göstərməyə, etimadın sosial funksiyalarını dəqiqləşdirməyə çalışır. Etimad mənşəyinə müraciət edərək, müəllif göstərir ki, təcrübədə o insanların, şüurunun uzunmüddətli inkişafın məhsulu kimi real münasibətlərdən yaranır və hər konkret mədəniyyətdə öz spesifik xüsusiyyətlərinə malikdir. Bu hallara əsaslanaraq, B.Rutkovski etimadın bir tərəfdən, konkret qruplarda şəxsiyyətlərarası real praktik münasibətlərdən, digər tərəfdən-şəxsiyyətin özünüdərk və əxlaqi şüurunun inkişaf səviyyəsindən asılıdır. O qeyd edir ki, etimad əxlaqi şüurun "bir insanın digərinin niyyətinin səmimiliyinə daxili əminliyindən" ibarət keyfiyyətcə xüsusi bir vəziyyətdir $(9$, s.12).

Oxlaqi şüurun xüsusi vəziyyəti olaraq, etimad əxlaqi hiss və fikirlərdən ibarətdir. Məhz buna görə etimad şəxsiyyətlərarası münasibətlərin əxlaqi tənzimləyicisidir. Beləliklə, müəllif etimad anlayışını əks etdirən spesifik obyekti ayırd edir. Onun fikrincə, bu obyektlə əxlaqi münasibətlərin xüsusi tərəfi fiksə edilir. Həmin münasibətlərin spesifikası ondan ibarətdır ki, onlar əxlaqi-ənənəvi borcla könüllü qarşılıqlı öhdəçiliklərə əsaslanır və bunlar cəmiyyətin şəxsiyyətə tələbləri nəticəsində yaranır və onun sayəsində etimadın sosial mahiyyətinin vurğulanması üçün əsas kimi çıxış edirlər.

Lakin qeyd etmək lazımdır ki, etimad anlayışı tək insanlar arasında əlaqələri nəzərdə tutmur, həm də şəxsin daxili subyektiv sferasının bu əlaqələrə münasibətini özündə ehtiva edir. Bununla bağlı B.Rutkovski yazır ki, "əgər şəxsin digər şəxsin niyyətinin səmimiliyinə daxili əminliyi olmasa, əgər bu şəxs digərinin davranışının əxlaq normalarına cavab verəcəyinə inanmasa bu zaman etimada əsaslanmış münasibətlər mövcud ola bilməz” (9, s.14).

Oslində etimad bir insanın digərinin mümkün davranışının proqramlaşdırılmasıdır ki, bu da həmin insanın biliyinə əsaslanır. Digəri haqqında bilik nə qədər dərin və əhatəli olarsa, bir o dərəcədə həmin şəxsin davranışını dəqiq proqnozlaşdırmaq olar. B.Rutkovski, təkid edir ki, etimad hər zaman dərk olunur, halbuki əxlaq dəyəri kimi çıxış edən etimad edilmiş insana münasibətə əsaslandığ 1 üçün risklə bağ lıdır.

Beləliklə, etimadı etik kateqoriya kimi öyrənən müəlliflər onu insan psixikasının rasional ifadələrinə aid edirlər. Olbəttə, etimad anlayışını tam şəkildə başa düşmək üçün onun əksi olan anlayışı dəqiqləşdirmək lazımdır.

Fəlsəfi etika nöqteyi-nəzərindən etimadın əksi etimadsızlıqdır ki, bu da insanın səmimiyyəti və düzgünlüyünün şübhə altına alan bir haldır. Həmin kateqoriyanı təhlil etməyə çalışan Y.Yançev diqqətini etimadın digər cəhətinə yönəldir. $\mathrm{O}$ da həmçinin etimadı əxlaqi münasibət kimi anlayır, lakin yazır ki, "etimad intim fikirlərin və hisslərin ötürülməsi və ya etimad edən obyektin davranışının öz konkret maraqları və xeyirxahlıq əsasında əxlaq norması ilə ziddiyyət təşkil etməyə və onun əsasında icra olunan hərəkətdir" (5, s.215).

Y.Yançevin fikrincə, "xeyirxahlıq" anlayışı məzmunca etimad anlayışından daha genişdir. Bu səbəbdən onları əlaqələndirmək olar və etimadın 
əxlaqi münasibətinin obyektiv təbiəti ziddiyyətli olduğundan, etimad anlayış1nın mahiyyətinə daha geniş anlam olan xeyirxahlığ əlavə etdikdə etimad insanlar arasında əxlaqi, könüllü, bir-birini tanımağa əsaslanan və konfidensial informasiyanın təhlili prosesidir. O, etimadın mahiyyətində 4 cəhəti ayırd edir:

1. Etimad-insanlar arasında namus, düzgünlük, vicdanlıq və sədaqətə əsaslanan əxlaqi münasibətlərdir;

2. Etimadda bir-birini tanımaq məqamı ayırd edilir;

3. Etimad könüllü, zorakılıq olmayan bir ifadədir;

4. Etimad intim hisslərin və fikirlərin ötürülməsi prosesidir (8, s.230).

Təhlillər göstərir ki, müəyyən ölçüdə etimad insanın digər insanlarla təmasının bütün sosial sferalarına daxildir.

Deməli, etimad etikanın vacib problemi olaraq dünya və insanın bütöv təmasına daxildir. Beləliklə, fəlsəfi etika nümayəndələrinin fikrincə etimadın insanların təmasında özünüaşkaretmə nöqteyi-nəzərindən hədsiz məhdudluğa malikdir. Bundan əlavə, belə anlayış onun psixoloji mahiyyətini tam əks etdirmir.

Olbəttə, etimadın bir etik əxlaq kateqoriyası kimi öyrənilməsinin təhlili onun bütün fenomenoloji xarakteristikaları haqqında nəticə çıxarmağa imkan vermir və bu hadisənin fenomenoloji məkanını məhdudlaşdırır. Bu səbəbdən psixoloji etimad və fəlsəfi inam anlayışı arxasında dayanan reallığ dərk etmək zərurəti ortaya çıxır.

Etimad və inam anlayışları arasında etimoloji əlaqə vardır. Lakin bu anlayışların ayırd edilməsi müəyyən nəzəri çətinliklər yaradır. Ona görə ki, inam fenomenini ənənəvi olaraq uzun müddət ərzində yalnız dini dünyagörüşə məxsus kateqoriya kimi tədqiq edirdilər. Allaha inam və etimadı həyatın yaradıcısı və qurucusuna olan inam və etimad kimi qəbul edir, eyni zamanda etimad nisbətən müstəqil elmi kateqoriya kimi əxlaqi-etik kateqoriyalara aid edirdilər.

Bu baxımdan etimad fəlsəfi etika çərçivəsindən kənarda mümkün olmurdu və yalnız insanların ünsiyyət sferasında özünü göstərirdi. Bununla belə etimad kateqoriyası fraqmentar olsa da təhlili heç bir klassik fəlsəfi etik sistemlərdə təqdim olunmamışdır. İzahlı lüğətlərdə təqdim olunan inam və etimad anlayışları bu anlayışların mahiyyətini, fərqli cəhətlərini tam aydınlaşdırmır (onların qismən sinonimlər kimi qəbul edilir) və mənası qaranlıq qalır.

Deməli, bu anlayışlarda hansı reallığın əks olunması haqqında sual qoyulması etimadın bir psixoloji fenomen kimi mahiyyətini anlamağa qismən imkan verir. Bu səbəbdən dil mədəniyyətində fəlsəfədə və fəlsəfi etikada mövcud olan, bu anlayışların izahına həsr olunmuş tədqiqatlara müraciət edərək, bu sözlərin arxasında duran reallığı differensiya etmək, etimad fenomeninin psixoloji və sosial-psixoloji təbiətini anlamaq zərurəti meydana çıxır.

Yalnız son illərdə baxılan kateqoriyanın mahiyyəti anlamına tərəf əhəmiyyətli addımlar atılmışdır. 1996-c1 ildə buraxılmış fəlsəfi lüğətində müəlliflər, dini və dünyəvi elmlərdə inamın öyrənilməsinin təcrübəsini ümumiləşdi- 
rərək, inam kateqoriyasının daha geniş və dərin izahını təklif edirlər. Məqalə müəlliflərinin fikrincə inam termini bir neçə mənada işlənir və bu səbəbdən onun toplam mənası insanın yüksək hissiyyata doğru iki əks yolun differensasiyası üçün yetərli deyil. Burda iki yol gostərilir: a) qapalı dünyaya xarici təcrübə və anlayışlar vasitəsi ilə yol; b) varlığın dolğunluğuna doğru insan ruhunu proobrazlarda, dərk olunan orijinalda birbaşa mövcudluğu vasitəsi ilə keçilən yol. Məhz bu səbəbdən ingilis dilli ədəbiyyatlarda hər iki terminlərin «faith və belief» istifadəsində terminoloji oxşarlıq vardır və bundan çıxış edərək müəlliflər digər dillərə qohum anlayışlar kimi daxil etməyi təklif edirlər.

Etimad və subyektiv əminlik, gözləmə və ümid formalarında, hissiyyat və rasional obrazların həqiqiliyini qəbul edən bir inam kimi təyin edirlər. Məqalənin təhlili göstərir ki, etimadı "belif" inamın formalarından birinə aid etmək olar. Psixoloji nöqteyi-nəzərdən etimad və "belif"- inam ümumilikdə subyektin obyektə münasibəti ilə bağlıdır və onların bərabərsizliyini təxmin etmok olar.

Qeyd etmək lazımdır ki, inam və etimad sinonim kimi işlənməsi və onların dialektik vəhdətdə götürülməsi müxtəlif fəlsəfi-psixoloji yanaşmalarda geniş əhatədə tədqiq edilmişdir. İnam qədimdən fəlsəfənin dini dünyagörüşü ilə əlaqə mövzusu idi və bu səbəbdən ona mistik, izah olunmaz qüvvə kimi baxılırdı. Rus filosofu Vişeslavtsevin inam haqqında yazır: «Tarix qanunla deyil, inamla yaradılır. İnam "ümidlərin hipostoz edilməsidir. O bizim qarşımızda, heç bir təcrübədə rast olunmayacaq arzulanan və gözlənilən mükəmməlliyi qoyur, hansı ki, "gözəgörünməzdir" o, on yaxșıya, yəni səmaviyə doğru cəhddir" (4, s.59). Digər sözlə inam mütləqə (absolyuta) aksioloji münasibətdir, o bizim qarşımızda, heç bir təcrübədə rast olunmayacaq arzulanan və gözlənilən mükəmməlliyi qoyur və gözəgörünməzdir.

Fəlsəfə tarixində mövcud inam nəzəriyyələrində bir qayda olaraq üç yanaşma tərzi özünü göstərir. Onları aşağıdakı kimi qruplaşdırmaq olar:

1. Emosional-inam. Burada inam üstünlüklə bağlı bir hiss kimi götürülür. (Yum, Cems və s.)

2. İntellektual inam. Burda inam intellekt fenomeni kimi izah edilir. (C. St. Mill, Brentano, Hegel va s.)

3. İradənin göstəricisi. Burda inamı iradənin atributu kimi tanıyır. (Dekart, Fixte və s.)

Ümumilikdə, inam kateqoriyası elmin inkişafı istiqamətləri ilə dəyişmişdir. P.Florenski fəlsəfə tarixində əsl inamın 2 formulasını qeyd edir və sonradan bunları inam mərhələsinin konsepsiyasına birləşdirir. Onun fikrincə "inanıram, çünki absurddur" (K.S. Tertullian 160-220), "inanıram ki, anlayım (Avqustin Blajenni 354-430) və "inanmaq üçün əminliyə” nail olmaliyam (Anselm Kenterberiyski 1033-1109)" tezisləri inamın mahiyyətini açır.

Qeyd edək ki, fəlsəfə tarixində ilk dəfə hələ İ.Kant inamı dini ənənədən ayırmışdır və inamı məntiqlə sübut ola bilməyən, lakin əxlaqi imperativin 
əsaslandırılması üçün zəruri olan ağıl mövqeyi kimi təqdim etmişdir. O hesab edirdi ki, inam məqsədə çatma imkanının həqiqətə çevrilməsidir. Onun fəaliyyət prosesində reallaşmasında inam-qəlbin daimi banisidir, son məqsədin imkan üçün təxmin ediləcək şərtdir və bu məqsədin mütləqliyi səbəbindən həqiqət kimi tanınandır. Halbuki, onun mümkünlüyünü və ya mümkünsüzlüyünü biz əvvəlcədən görə bilmərik. Beləliklə, İ.Kant göstərmişdir ki, inam qoyulmuş məqsədlə fəaliyyəti əlaqələndirən vacib şərtdir.

Hal-hazırda bir çox müəlliflər bu fikirdədirlər ki, dini inamla inamın digər növləri arasında mahiyyətcə fərq yoxdur. İnam insanın zəruri keyfiyyətidir. $\mathrm{O}$ hər zaman məqsədyönlüdür, emosional çalarlıdır və onun müəyyən obyekti vardır. Bu səbəbdən inam tədqiqatçılar tərəfindən insanın davranış xarakterini təyin edən, produktiv şüur halı kimi götürülür. On avtoritetli xarici tədqiqatçılardan biri P. Conson yazır: "Yəqin ki, təbii inanmaq tendensiyası mövcuddur. Hər bir insan inanandır. Hamı eyni şeyə inanmır, lakin hər kəs nəyəsə inanır" (4, s.61).

Amerikalı tədqiqatçılar M.Ostou və B.Şarfsteyn hesab edirlər ki, "inanmaq qidalanmaq qədər zəruridir" (4, s.61).

Psixologiya klassikləri arasında inam kateqoriyasının işlənməsində xüsusi yer U.Cemsə məxsusdur. O yazır: "İnam-nəzəri baxımdan şübhə yarada biləcək bir şeydə əminlikdir, inamın ölçü vahidi hərəkətə hazırlıqdır və bu səbəbdən demək olar ki, inam məqsəd uğrunda hərəkətə hazır olmaq deməkdir. Baxmayaraq ki, həmin məqsədin uğurla əldə olunub-olunmayacağı bizə məlum deyil» (4, s.62).

Digər amerikan filosofu C.Santayananın fikrinə görə, ümumiyyətlə heç bir obyekt haqqinda bilik həqiqi ola bilməz. O da Platon kimi hissi təcrübədən alınan bilikləri rəy adlandırır və belə hesab edir ki, o, ancaq insanın inamı (belief) sayəsində bilik kimi dəyərləndirilir. İnam güclü olanda, bilik ehkama çevrilir. Təsadüfi deyildi ki, C.Santayana hər hansı bir biliyi nisbi hesab edir və onu ehkamlaşdırılmasını «heyvani inam» adlandırır (2).

Müasir dövrdə Q.Ollportun 1960-c1 ildə inam haqqında ideyası ümumi qəbul edilib. O hesab edirdi ki, bütün insanlar inanır və inamsızlıq da inamın bir formasıdır. İnam bizim hədd obyektinin reallığına münasibətə keçdiyimiz əminlik və ya təsbitdir. İstənilən pozitiv hisslər mütləq, qaçılmaz olaraq hansısa dərəcədə inam yaradır və bu inam hər zaman hərəkətlərlə müşayiət olunur. Çünki biz inandığımızı icra etmək, həyata keçirməyə çalışırıq.

Məşhur psixoloq E.Frommun da inamın funksiyası və mahiyyəti haqqında fikirləri də çox maraqlıdır. $\mathrm{O}$ da hesab edir ki, inam tək teologiyanın predmeti deyil və heç də rasional düşüncəyə zidd deyil. E.Fromm insanın inamsız yaşaya bilməyəcəyi haqda fikirlə razıdır: "Məgər biz dostlarımıza, sevdiklərimizə, özümüzə inanmamalıyıq? Biz inamsız yaşaya bilərik? Həyatımızın normalarının təsirli olmasına inanmaya bilərik?" Və sonra cavab verir: "Həqiqətən inamsız insan ümidini itirir və özü - öz mövcudluğundan qorxur" 
(5, s .62).

Müasir hermenevtika liderləri Pol Riker və Hans Deorq Qadamer inam fenomeni anlayışını əhəmiyyətli şəkildə genişləndirmişdir. Belə ki, Qadamer inamı anlam və tarix problemləri ilə əlaqələndirmiş və gnoseologiyada tutduğu yeri açıqlamışdır. Bu müəllif deyir ki, inam istənilən real öyrənmə və özünüidarəetmə aktına daxildir. P.Riker deyir ki, inam ciddi biliklə bağlı olan obyektiv anlayışından fərqli olaraq ekzistensial anlayışdır. Onun fikrincə problem onları birləşdirməkdədir. Həmçinin müəllif inamın şəxsiyyətin dəyər oriyentasiyaları üçün əhəmiyyətini açıqlamışdır. Çünki insan dəyərləri nə subyektiv, nə də obyektivdir. Onlar əhəmiyyətlidir. Lakin dəyər mənasının qiymətləndirilməsi inamın işidir. Beləliklə, inamın mahiyyəti haqqında müasir təsəvvürlərin təhlili göstərir ki, inam psixoloji fenomendir və öz təbiətinə əsasən subyektivdir. Belə ki, insan subyektiv reallığının ayrılmaz atributu kimi çıxış edir. İnsan mövcudluğunun bütün sferalarını inam təşkil edir, məhz o varlıq bütövlüyünün modelləşdirilməsini yerinə yetirir. Onsuz nə yaradıcı fəallıq, nə də şəxsin ümumilikdə inkişafı mümkündür.

Aparılmıs tədqiqatlar inam subyekti və obyektinin təmasını belə təsvir etməyə imkan verir. Etimad haqqında söhbət gedərsə, subyektin inam obyektinə müəyyən dəyər münasibətinin qurulması və ya mövcudluğu təxmin edilir və bununla onlar arasında distansiyanın götürülməzliyi şərtləndirilir və bu zaman münasibətlər subyekt-obyekt şəkli alır. İnam haqda söhbət gedəndə ilkin olaraq münasibətlər subyekt-obyekt $(\mathrm{S}-\mathrm{O})$ münasibətləri kimi görünür. Lakin onlar belə bir münasibətə keçid ala bilər: S-O-S. Bu onu bildirir ki, qəbul etmə aktı yerinə yetiriləndə, yəni əsl inam qəbulu subyektin, insanın inandığı məzmunla bərabərliyini təxmin edərək eyni zamanda subyektin şüurunun məzmunu da dəyişdirilir. Bu zaman inamın məzmunu mahiyyətə çevrilir. Beləliklə, əsl inam şəxsiyyət sosializasiyasının vacib mexanizmi statusu qazanır. Etimad qismində mövcud olan inam forması digər funksiyaları yerinə yetirir. Buna görə etimadın vacib funksiyası obyektin və subyektin qarşılaşdırılmasıdır. Etimad yalnız ali hissiyyat obyektlərinə nisbətdə inam aktından əvvələ gələ bilər.

Bütün bunlar göstərirki, fəlsəfədə inam kateqoriyasının öyrənilməsinin müasir vəziyyətinin təhlili inam və etimadı ayıraraq, öyrənilən fenomenin nəzəri modelini qurmağa imkan yaradır, eləcə də etimadın insanın həyat sferalarına təsir edən refleksiv fenomen kimi qiymətləndirməyə şərait yaradır.

Ümumilikdə, götürsək psixologiyada etimad probleminin mahiyyətini açarkən, tədqiqatçılar etimadı yalnız anlayışlar kimi yox, həm də onu insan münasibətlərində sosial və şəxsiyyətlərarası funksiya daşı1ı̆̆ını da qeyd edirlər. Eləcə də inam insanın mənəvi aləminin strukturunda yer tutan ən önəmli komponentlərdən biridir. İnam insanın idraki qabiliyyətinə, öz zövqünə, qiymətləndirmə qabiliyyətinə və nəhayət, öz əməli fəaliyyətinin motivinə bir vasitədir.

Beləliklə, inamın əsasında qəbuletmə aktı, etimadın əsasında subyektlə 
obyektin təması (toxunması) zamanı yaranan münasibətlə bağlı spesifik vəziyyət (yaşant1, həyəcan) dayanır.

Beləliklə, aparılmış tədqiqatlara əsasən etimadla inam arasındakı fərq ondan ibarətdir ki, inam əsassiz olaraq nəyin isə həqiqət kimi qəbul edilməsi ilə bağlıdır. Etimad isə müəyyən etibarlı münasibətlərin davam etdirilməsindən və ya dayandirılmasından ibarətdir.

Ümumilikdə etimad və inam anlayışlarının öyrənilməsinə həsr olunmuş işlərin təhlili belə bir qənaətə gəlməyə imkan verir ki, hər iki anlayış psixoloji problem olaraq cidd elmi araşdırma tələb edir.

\section{Odəbiyyat:}

1. Abbasova A. Etimad etik-fəlsəfi anlayış kimi//Doktorantların və gənc tədqiqatçıların XVI Respublika elmi - praktik konfrans1, Bakı, 2012, s.243-245.

2. Xəlilov S. "Mənəviyyat fəlsəfəsi"

3. Xəlilov S.S. Azərbaycançılıq məfkurəsi. Bakı: Azərbaycan Universiteti, 2006. $420 \mathrm{~s}$.

4. Зинченко В.П. Психология доверия. Самара: 2001,104 с.

5. Купрейченко А.Б. Психология доверия и недоверия. М.: РАН во Институт, 2008, 564 с.

6. Мальцева А.П. Философия доверия. -Человек. 2012, № 3, с. 19-27.

7. Рутковский Б.А. Понятие доверия в марксистской этике. Дис. канд. филос. наук. Кіев: 1987, 187 с.

8. Селигмен А. Проблема доверия: Пер. с англ. М.: Идея-Пресс, $2002,254 \mathrm{c}$.

9. Скрипкина Т.П. Психология доверия. М.: Академия, 2002, 264 с. 